\title{
KEBIJAKAN PENGELOLAAN RUANG TERBUKA HIJAU (RTH) TAMAN FLORA SURABAYA
}

\author{
Nila Rosawatiningsih \\ Departemen Pengembangan Sumber Daya Manusia Sekolah Pascasarjana, \\ Universitas Airlangga, Surabaya, Indonesia \\ nilarosawatiningsih@gmail.com
}

\begin{abstract}
Abstrak
Tingginya minat masyarakat khususnya masyarakat perkotaan untuk melakukan kegiatan berwisata membuat pemerintah kota harus melakukan inovasi dengan mengembangkan Ruang Terbuka Hijau (RTH) sebagai suatu tempat yang memiliki fungsi kompleks. Penelitian ini mengulas lebih dalam salah satu Ruang Terbuka Hijau (RTH) yang dimiliki kota Surabaya yakni Taman Flora yang sekaligus menjadi taman kota besar dengan fasilitas penunjang yang lengkap. Ulasan ini juga mendeskripsikan kegiatan apa saja yang dilakukan orang-orang saat mengunjungi Taman Flora sehingga menghasilkan suatu struktur sosial yang saling berhubungan dan tidak dapat dipisahkan. Metode yang digunakan pada penelitian ini adalah kualitatif dan analisis deskriptif. Hasil penelitan menyebutkan bahwa fungsi Taman Flora sangat kompleks meliputi fungsi edukasi, fungsi kesehatan, fungsi perekonomian dan fungsi interaksi. Seluruh fungsi tersebut bisa berjalan karena pengunjung, pemerintah, pihak swasta, pedagang, pengelola dan masyarakat menjalankan peran yang disandang sesuai dengan statusnya. Setiap struktur yang menjalankan tugasnya dengan baik akan memberikan pengaruh yang baik pula terhadap kondisi Taman Flora Surabaya.
\end{abstract}

Kata kunci: Ruang terbuka hijau, fungsi taman kota, taman flora Surabaya

\begin{abstract}
The high interest of the community specifically for tourism activities makes the city government must innovate by developing Green Open Space (RTH) as a place that has complex facilities. The Green Open Space (RTH) provided by the city of Surabaya is the Flora Park which is also a big city park with complete supporting facilities. This review also describes what activities people do when visiting the Flora Park so as to produce social structures that are interrelated and cannot be completed. The method used in this study is qualitative and descriptive analysis. Research results on the functions of Flora Park are very complex discussing the functions of education, health functions, financial functions and interaction functions. All these functions can work because visitors, the government, the private sector, managers, traders and the community carry out their roles according to them status. The role that each structure carries out has a huge influence on the existence and development of Taman Flora Surabaya.
\end{abstract}

Keywords: Green open space, function of city park, flora park surabaya

Subrhited: 20-03-2019; Accepted: 29-04-2019; Published: 30-04-2019

*Kotespondensi: Departemen Pengembangan Sumber Daya Manusia Sekolah

Pascasarjana, Universitas Airlangga, Kampus C Mulyorejo, Surabaya, Jawa Timur 60115

Emall: nilarosawatiningsih@gmail.com 


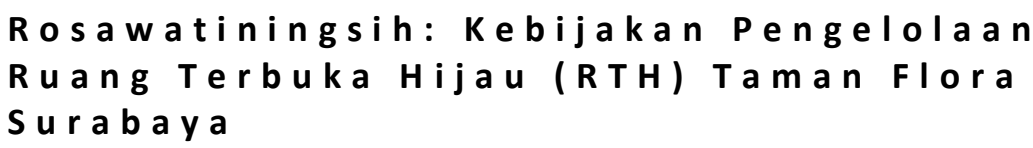

\section{PENDAHULUAN}

Pariwisata merupakan hal-hal yang dapat membuat seseorang merasa terhibur saat melakukan perjalanan wisata.Undang-undang No.10 Tahun 2009 (Anon n.d.; Anon n.d.) menyebutkan bahwa pariwisata merupakan ragam dari kegiatan berwisata yang memiliki fasilitas serta pelayanan yang diberikan oleh sesama pelancong, masyarakat lokal, pemerintah daerah dan pengusaha. Berwisata seolah telah menjadi budaya khususnya bagi masyarakat yang tinggal di kota besar.Hal ini terjadi salah satunya karena faktor kondisi kota yang identik dengan keramaian, banyaknya gedung pencakar langit, bangunan tinggi, kemacetan yang menimbulkan polusi udara dan bisa mengakibatkan stress (Anon n.d.). Beberapa masyarakat yang tinggal di kota memilih untuk memperoleh atraksi wisata dengan fenomena alam yang kontras dengan kondisi kota. Untuk menjawab permasalahan yang dialami oleh masyarakat kota maka pemerintah menyediakan Ruang Terbuka Hijau (RTH) sebagai solusi akan kebutuhan berwisata(Soekadijo 2000).

Penelitian terdahulu yang dilakukan oleh Jennifer Wolch, Jason Byrne, dan Joshua Newell(Wolch, Jennifer n.d.)menyebutkan bahwa Ruang Terbuka Hijau (RTH) memiliki manfaat bagi aktivitas fisik, kesejahteraan psikologis dan kesehatan masyarakat kota. Penelitian tersebut membandingkan kondisi Ruang Terbuka Hijau (RTH) khususnya taman yang dimiliki Amerika Serikat dan Cina. Di Amerika(Randrup, T.B., Konijnendijk, C.C., Dobbertin, M.K. 2005), beberapa kota yang lingkungannya dianggap miskin taman telah menerapkan strategi untuk meningkatkan taman kotanya. Hal serupa juga dilakukan di Cina, dimana negara memberi kontrol penuh terhadap ketersediaan lahan untuk penghijauan kota.(Zhao 2016)Sidong Zhao menyebutkan bahwa fungsi taman di Cina lebih bersifat industrial bagi suatu kota karena pertumbuhan, bentuk, fungsi perkembangannya semakin kompleks.Dalam Permendagri No. 01 tahun 2007 pasal 24 disebutkan bahwa RTH bisa digunakan sebagai tempat rekreasi aktif yakni pemanfaatannya berhubungan dengan aktivitas fisik, sementara RTH sebagai rekreasi pasif memiliki keterkaitan dengan pemanfaatan emosional dan aktivitas rohani.

Pada ulasan kali ini, ketersediaan lahan di kota Surabaya untuk pemanfaatan RTH disoroti lebih dalam karena mampu menyediakan 26\% dari 33.306,30 total luas kotanya (Maria Ulfa 2018) Kota Surabaya memiliki kontribusi paling besar 
dalam penyediaan RTH dibandingkan dengan kota lain di Jawa Timur seperti Batu, Madiun, Blitar, Malang, Probolinggo, Kediri, Pasuruan, Mojokerto. Salah satu RTH yang dimiliki Surabaya diwujudkan dalam bentuk taman kota. Pengertian taman kota sendiri menurut (Konijnendijk 2003) adalah area ruang terbuka yang mayoritas didominasi oleh vegetasi dan air, dan umumnya disediakan untuk penggunaan umum atau publik. Sementara itu, fungsi taman kota di Surabaya sebagai RTH selain untuk mempercantik kota dan memiliki fungsi ekologi juga berfungsi menambah ekonomi masyarakat sekitar, fungsi sosial dan budaya.

Surabaya memiliki banyak taman kota diantaranya Taman Persahabatan, Taman Keputran, Taman Undaan, Taman Apsari, Taman Wira Surya Agung, Taman Pakal, Taman Kombes Pol M Durayat, Taman Ekspresi, Taman Prestasi, Taman Sulawesi, Taman Karimun Jawa, Taman Mundu, Taman Surya, Taman Flora Bratang, Taman Flora Wonorejo, Taman Kunang-Kunang, Taman Ronggolawe, Taman Jagir, Taman Pelangi, Taman Jayengrono,Taman Krembangan Timur, Taman Kalongan, Taman Lansia, Taman Nambangan, Taman Teratai, Taman Paliatif, Taman Barunawati dan Taman Harmoni yang merupakan taman baru di daerah Keputih (Anon n.d.). Fokus penelitian ini tertuju pada Taman Flora Surabaya yang bagi sebagian warga Surabaya dikenal dengan nama Kebun Bibit karena dulunya merupakan lokasi pembibitan tanaman. Perubahan nama dilakukan pemerintah kota Surabaya seiring dengan perubahan fungsi. Fungsi dari Kebun Bibit Bratang ini dipindahkan ke daerah Wonorejo dan konsepnya diubah menjadi seperti kebun raya atau hutan mini di perkotaan. Nama Taman Flora dirasa pemerintah sangat tepat karena taman ini berfungsi menjadi tempat konservasi tanaman karena memiliki keanekaragaman hayati, seperti tanaman perdu atau semak, tanaman pelindung, tanaman palem dan tanaman langka (Anon 2013). 
Rosawatiningsih: Kebijakan Pengelolaan

Ruang Terbuka Hijau (RTH) Taman Flora

$S$ u $r$ a b a y

Tabel 1.

Taman Kota Besar di Surabaya

\begin{tabular}{lll}
\hline \hline Nama Taman & $\begin{array}{l}\text { Jumlah } \\
\text { Pengunjung } \\
\text { (orang) }\end{array}$ & $\begin{array}{l}\text { Luas Taman } \\
\left(\mathrm{m}^{2}\right)\end{array}$ \\
\hline Taman Flora & 71.889 & 31.000 \\
\hline Kebun Bibit Wonorejo & 59.143 & 50.000 \\
\hline Taman Mundu & 32.530 & 4.800 \\
\hline Taman Prestasi & 12.406 & 6.000 \\
\hline Taman Bungkul & 8.654 & 900 \\
\hline Sumber : Dinas Kebersihan dan Pertamanan Kota Surabaya
\end{tabular}

Surabaya mempunyai beberapa taman yang dikategorikan sebagai taman besar. Data dinas Kebersihan dan Pertamanan Kota Surabaya pada tahun 2016 menyebutkan bahwa Taman Flora memiliki jumlah pengunjung terbanyak dibanding dengan taman lain, lebih dari 70.000 dalam satu tahun. Hal ini terjadi bisa saja karena keberadaan Taman Flora sebagai taman kota di Surabaya sudah banyak diketahui masyarakat karena bukan termasuk kategori taman kota baru. Jumlah tersebut masih kurang besar karena pemerintah ingin terus meningkatkan pariwisata kota sehingga berdampak pada pemasukan daerah.

Taman Flora pernah mengalami kasus sengketa lahan dengan pihak swasta, sehingga sempat menjadi pusat perhatian masyarakat kota Surabaya. Ketenaran taman ini disebabkan juga olehkondisitaman yang semakin baik. Selain itu, letak strategis Taman Flora menjadi nilai tambah karena mempermudah pengunjung. Dengan adanya tambahan satwa di Taman Flora menjadi daya tarik tersendiri bagi pengunjung khususnya anak-anak. Fasilitas lain yang dimiliki adalah area kesehatan, area outbound, green house, kandang rusa, sangkar burung raksasa, kolam ikan dengan air mancur, kolam air mancur, area playground, sentra kuliner RMI, pendopo, mushola, toilet, keran air, bangku taman, wifi, Ruang Baca (Taman Bacaan Masyarakat), Broadband Learning Center (BLC).

Banyaknya kelebihan yang dimiliki Taman Flora maka taman ini sangat layak ntuk dijadikan sebagai salah satu destinasi wisata kotq Surabaya. Namun yang menjadi permasalahan adalah kurangnya minat masyarakat terhadap potensi wisata dengan atraksi alam yang ada di perkotaan. Adanya anggapan bahwa wisata di kota besar monoton dan kurang menarik karena fasilitasnya kurang lengkap serta sarana dan prasarananya sangat minim. Masyarakat juga 


\section{2| The Journal of Society and Media 3(1)}

menganggap pemerintah kota kurang fokus pada pengembangan fungsi taman kota sehingga banyak taman yang mangkrak. Adanya anggapan negatif tersebut bisa berdampak panjang menyangkut aspek sosial, ekonomi, budaya masyarakat sekitar. Penggalian dan pengembangan potensi taman kota harus terus dilakukan untuk meningkatkan kualitas taman tanpa mengganggu atau merusak kehidupan sosial yang telah ada sebelumnya. Sebagaimana yang diungkapkan oleh Pitana dan Gayatri (Pitana 2005) bahwa mempertimbangkan aspek sosial-budaya dari masyarakat sekitar yang ada di daerah tujuan wisata sangat penting bagi pembangunan wisata berupa taman Dengan adanya taman sebagai tempat wisata harus mampu memberikan berbagai dampak positif bagi seluruh lapisan masyarakat, oleh karena itu diperlukan kerjasama dari berbagai pihak seperti pemerintah dalam membuat kebijakan, pengelola taman sebagai orang yang paham betul bagaimana cara menjaga kondisi taman, masyarakat sebagai penikmat taman dan pihak swasta harus selalu bekerjasama agar tujuan pengembangan taman kota sebagai Ruang Terbuka Hiaju (RTH) bisa tercapai.

\section{METODE PENELITIAN}

Metode yang digunakan yaitu deskriptif dengan pendekatan kualitatif (Moleong 2005). Lokasi penelitian dilakukan di Taman Flora Surabaya yang terletak di Jalan Manyar No.80A, Kelurahan Barata Jaya, Kecamatan Gubeng, Surabaya. Pemilihan lokasi tersebut sebagai tempat penelitian dikarenakan Taman Flora termasuk dalam taman kota besar di Surabaya dengan lokasi strategis sehingga akses menuju lokasi sangat mudah dijangkau (Pramitasari 2009). Selain itu, Taman Flora memiliki fasilitas memadai yang dapat dinikmati secara gratis oleh seluruh kalangan (Barbosa 2006). Peneliti menggunakan teknik observasi langsung untuk memperoleh data seperti sejarah taman, lokasi, jumlah pengunjung, batas wilayah, struktur organisasi, jadwal kegiatan, koleksi flora dan fauna, fasilitas serta sarana dan prasarana yang diimiliki Taman Flora Surabaya(Yin 2008). Selain itu, untuk memperoleh data, peneliti melakukan wawancara dengan orang-orang yang memiliki keterkaitan dan pengetahuan terhadap topik yang diteliti yakni Kasie taman di Dinas Kebersihan dan Pertamanan kota Surabaya, Kepala UPTD, Kasie Rekreasi dan Hiburan Umum Dinas Kebudayaan dan Pariwisata kota Surabaya,Pengelola Taman Bacaan Masyarakat, Instruktur Broadband Learning Center, Koordinator Rumah 


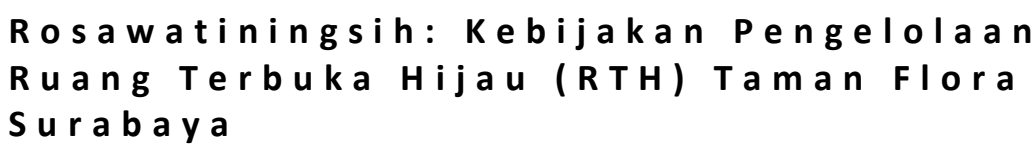

Kompos, Petugas Keamanan, Aktivis Lingkungan, Pedagang,Pengunjung Umum hingga Tukang Parkir.

Setelah data-data tersebut diperoleh, peneliti menggunakan teori struktural fungsionalisme dari Radcliffe Brown yang menurut Kaplan dan Manners (Kaplan, David \& Manners 2002) teori tersebut berasumsi bahwa segala fenomena yang ada pada kehidupan manusia diibaratkan sama dengan susunan organisme tubuh manusia, setiap bagian yang ada memiliki tugas dan fungsi masing-masing yang harus selalu dijalankan untuk menjaga keberlangsungan proses kehidupan. Tujuan peneliti menggunakan teori tersebut adalah untuk mengetahui status dan peran setiap stakeholder dalam keterlibatannya dengan Taman Flora Surabaya(Irmadella 2018). Selanjutnya, peneliti melakukan analisis data dengan cara melakukan verifikasi kepada informan, lalu data dipilah sesuai dengan kebutuhan dan diinterpretasi agar mampu menjelaskan fenomena yang diteliti dengan mudah (Creswell 2015).

\section{HASIL DAN PEMBAHASAN}

Pemerintah kota Surabaya memberikan fokus lebih terhadap pengelolaan taman-taman kota Surabaya yang dulunya terbengkalai. Salah satu cara yang dilakukan yakni dengan menjalin kerjasama dengan berbagai pihak untuk melakukan pengembangan taman kota. Kerjasama yang dilakukan berkaitan dengan kolaborasi terutama dalam hal pembiayaan, pengembangan dan perawatan(Iswari 2014). Sesuai dengan Peraturan MenteriPU No. 05/PRT/M Tahun 2008 (Anon n.d.) tentang. PedomanPenyediaan dan Pemanfaatan Ruang Terbuka Hijau diKawasan Perkotaan yang menyebutkan bahwa pengelolaan RTH pada era sekarang ini harus dilakukan secara kolaboratif. Dengan dilibatkannya berbagai pihak, diharapkan mampu membuat pengelolaan taman menjadi semakin efektif. Dengan adanya kebijakan tersebut kini Taman Flora memiliki koleksi 462 batang tanaman yang terdiri dari 70 jenis tanaman perdu dan semak, 61 jenis tanaman pelindung, 21 jenis tanaman langka, dan 17 jenis tanaman palem berjumlah lebih dari 210 batang. Sehingga Taman Flora Surabaya saaat ini telah memiliki total 169 jenis tanaman (Surabaya 2015). Tidak hanya itu, Taman Flora juga memiliki jenis fauna yang datanya dapat dilihat dalam tabel 2. 
Tabel 2.

Jenis Fauna Taman Flora Surabaya

\begin{tabular}{llll}
\hline No. & Nama & Nama Ilmiah & Jumlah \\
\hline 1. & Ayam Kate & Gallus Gallus & 15 ekor \\
2. & Rusa Bawean & Axis Kuhlii & 14 ekor \\
3. & Kancil & Tragulus Kanchil & 10 ekor \\
4. & Rusa Tutul & Axis Axis & 8 ekor \\
5. & Burung Jalak Kebo & Acridotheres Javanicus & 6 ekor \\
6. & Burung Jalak Nias & Leucopsar Rothschildi & 5 ekor \\
7. & Burung Jalak Rio-rio & Scissirostum Dubium & 5 ekor \\
8. & Burung Merak & Pavo Cristatus & 2 ekor \\
9. & Burung Kakak Tua Jambu Kuning & Cacatua Sulphurea & 2 ekor \\
10. & Kalkun & Meleagris & 2 ekor \\
11. & Kelinci & Lepus Curpaeums & 1 ekor \\
12. & Ayam Ketawa & Gallus Gallus Domesticus & 1 ekor \\
13. & Ikan Mas & Cyprinus Carpio & 1000 ekor \\
14. & Ikan Nila & Oreochromis Niloticus & \\
\hline
\end{tabular}

Sumber : Arsip Pengelola Taman Flora Surabaya

Konflik yang pernah dialami Taman Flora antara pihak Pemerintah Kota dengan PT Surya Inti Permata membuat keberadaannya makindisadari masyarakat. Adanya ketakutan dari masyarakat jika pengelolaan Taman Flora Surabaya jatuh ke tangan pihak swasta karena akan disalahgunakan untuk mencari keuntungan dan pengalihan fungsi aset kota menjadi pertokoan sangat besar pada waktu itu. Pemerintah berperan besar untuk menentang keras terjadinya hal tersebut. Tidak hanya itu, banyaknya gerakan penolakan dari masyarakat menghasilkan dampak positif dan membuat pengelolaan Taman Flora jatuh kembali ke tangan pemerintah. Setelah terjadinya permasalahan tersebut, pemerintah terus menerus mengembangkan potensi yang ada di Taman Flora agar dapat digunakan sebagai ikon Kota Surabaya. Pengembangan dilakukan secara bertahap dengan memprioritaskan fasilitas utama (Carmona 2003).

Kini, kelebihan Taman Flora Surabaya dibandingkan dengan taman lain terletak pada kelengkapan sarana dan prasarananya. Hal tersebut sekaligus menjadi bukti bahwa ada struktur sosial yang menjaga agar segala kegiatan yang ada di Taman Flora bisa berjalan sebagaimana mestinya(Rakhsandehroo, Mehdi 2015). Taman Flora Surabaya memiliki banyak sarana dan prasarana yang menunjang kegiatan pengunjung dalam berwisata (Bjerke, T\&Strumse 2006). Adanya sarana dan prasarana tersebut membuktikan adanya fungsi rekreasi, 


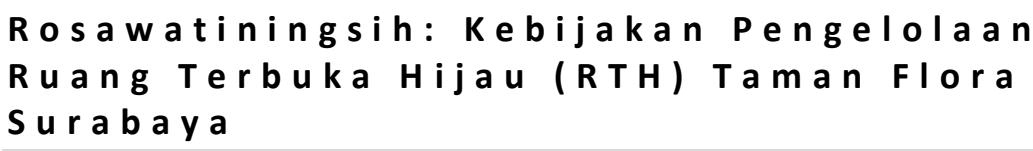

fungsi edukasi, fungsi interaksi, fungsi kesehatan dan fungsi perekonomian (Saifuddin 2005). Untuk lebih jelasnya dapat dilihat pada gambar 1.

Gambar 1.

Denah Taman Flora Surabaya

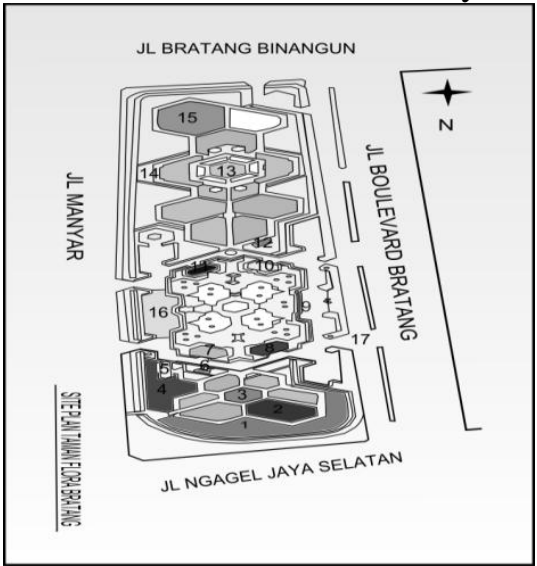

Sumber : Arsip Pengelola Taman Flora Surabaya

Keterangan gambar:

1. Kandang hewan rusa 10. Pendopo Alternatif

2. Sangkar burung besar 11. Broadband

3. Kolam ikan Learning Center (BLC)

4. Tempat outbound 12. Toilet

5. Toilet 13. Playground

6. Musholla 14. Taman Kecil

7. Kantor Pengelola 15. Danau

8. Green house 16. Taman promosi kesehatan

9. Pendopo Utama 17. Pintu masuk utama

Dari fasilitas yang ada di Taman Flora, ada orang-orang didalamnya yang menjalankan status dan peran sesuai dengan tugasnya masing-masing. Jika dianalisis dengan teori struktural fungsionalisme dari Radcliffe Brown maka hal tersebut sangatlah sesuai karena Brown menggunakan model organisme tubuh manusia yang menjelaskan bahwa jika ada salah satu bagian yang tidak menjalankan fungsinya dengan baik akan menghambat terjadinya kinerja dari orang lain. Sehingga pemerintah kota Surabaya, pihak swasta, masyarakat harus bekerjasama untuk mengembangkan keberadaan Ruang Terbuka Hijau Taman Flora(Laurie 1986).

Taman Flora Surabaya memiliki banyak sarana dan prasarana yang menunjang kegiatan pengunjung dalam berwisata. Adanya sarana dan prasarana tersebut membuktikan adanya fungsi rekreasi, fungsi edukasi, fungsi interaksi, 
fungsi kesehatan dan fungsi perekonomian. Untuk lebih jelasnya penjabaran teori dengan data hasil lapangan akan diuraikan sebagai berikut.

\section{Fungsi Rekreasi}

Sebagai tempat rekreasi, Taman Flora telah memenuhi persyaratan seperti aspek kebersihan, keindahan dan keamanan yang memadai. Kebersihan Taman Flora selalu terjaga baik saat ramai ataupun sepi pengunjung. Petugas kebersihan memiliki tugas dan peran untuk menyapu taman saat pagi, siang dan sore. Sampah yang dihasilkan pengunjung dikumpulkan dan diolah di Rumah Kompos. Penyiraman tanaman dilakukan sesuai dengan jadwal yang sudah disepakati pengelola (Pertamanan 2014). Kesadaran untuk menjaga kebersihan dilakukan pula oleh pengunjung. Terbukti ketika pengunjung berpiknik, beberapa dari mereka membawa tempat sampah dari kardus bekas minuman.

Selain itu, sebagai tempat rekreasi, faktor keamanan juga tak kalah penting untuk dilakukan karena mayoritas pengunjung taman adalah anak-anak. Taman Flora harus mampu menjadi kawasan ramah lingkungan bagi pengunjungnya. Keamanan taman dilakukan dengan adanya pagar pembatas yang mengelilingi dimaksudkan agar pengunjung anak-anak tidak berlarian ke luar karena posisi taman diitari jalan raya.Bentuk lain dari keamanan yang ada di dalam Taman Flora adalah pemusatan pintu masuk di sebelah utara dengan tujuan agar petugas dapat dengan mudah mengawasi pengunjung yang lalu lalang. Banyaknya rambu peringatan di titik yang dianggap berbahaya seperti danau, kolam, dan kandang rusa dilakukan untuk meningkatkan kewaspadaan orang tua dalam mengawasi anaknya.

Kegiatan piknik dilakukan pengunjung dengan membawa peralatan seperti tikar, karpet hingga koran sebagai alas duduk lesehan. Beberapa dari mereka memilih spot yang dianggap teduh untuk bersantai ria, memakan bekal makanan yang telah dibawa atau sekadar bercengkrama. Para pengunjung merasa senang karena keberadaan taman saat ini mulai membaik, fasilitas penunjang dapat dinikmati tanpa mengeluarkan biaya sedikitpun (Sulis Tia Ningsih, Ucha Jaya Sucipta Jaya Sucipta 2018). Dengan luas kurang lebih 3,1 hektar Taman Flora memiliki 43 spot mainan yang menjadi nilai tambah dibandingkan taman lain. 


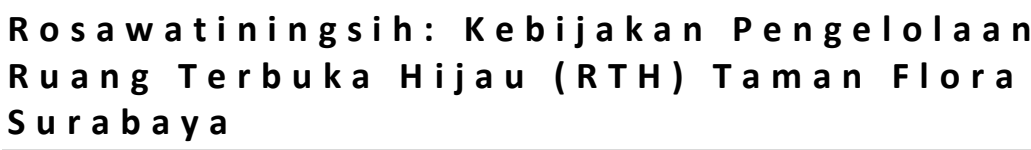

\section{Fungsi Edukasi}

Fungsi edukasi dari Taman Flora sangat menyasar seluruh pengunjung tanpa memandang lapisan usia. Keunggulan dalam keanekaragaman jenis hayatinya yang berjenis palem, semak, perdu tanaman pelindung hingga tanaman langka. Keanekaragaman satwa membuat Taman Flora layaknya kebun binatang. Area fauna yang terdiri dari kolam ikan, kandang rusa, dan sangkar burung raksasa bisa dijadikan sebagai objek edukasi. Berdasarkan observasi langsung yang dilakukan peneliti, beberapa siswa SD melakukan kegiatan menggambar disebelah kandang rusa yang dijadikan sebagai objek gambar yang menarik.Adanya rusa juga membuat para siswa tidak bosan dalam menggambar karena bisa mengerjakan sambil mengawasi pergerakan rusa. Sarana edukasi di area fauna juga dilakukan beberapa orang tua yang menemani anaknya memberi makan hewan. Para orang tua mengajari anaknya tentang jenis hewan dan bagian-bagian tubuh hewan seperti kepala, tanduk, rusa.

Banyaknya atraksi penunjang kegiatan edukasi, pengunjung tidak hanya berekreasi tapi juga belajar banyak hal baru. Pelajar mulai dari PAUD hingga mahasiswa bisa menimba ilmu di tempat ini. Kegiatan belajar dengan background alam menciptakan suasana berbeda yang mampu meningkatkan semangat para siswa. Untuk mengakomodasi berbagai kegiatan, pengelola menyiapkan dua pendopo yang bisa digunakan oleh semua orang. Pendopo utama lebih besar dan terletak dekat dengan pintu masuk utama, sementara pendopo kedua lebih kecil ukurannya. Pada saat peneliti melakukan observasi ditemukan kegiatan pagelaran budaya tari remo, kegiatan tematik, arisan keluarga,yudisium, outbound, kemah yang dilakukan sekolah-sekolah, lomba menggambar, mewarnai, diskusi hingga pengajian.

Fungsi edukasi dari Taman Flora tidak terpusat di satu titik saja, melainkan tersebar ke berbagai spot. Pengunjung banyak yang memilih spot taman yang memiliki pohon rimbun sehingga menghasilkan kesan sejuk karena terhindar dari sinar matahari. Pengunjung yang sudah berencana mengadakan kegiatan yang mengandung unsur pendidikan telah mempersiapkan perlengkapan seperti pengeras suara untuk mempermudah dalam memberikan informasi kepada peserta saat kondisi taman ramai. Segala kegiatan edukasi ataupun sosialisasi yang dilakukan di Taman Flora hampir tidak ada yang memiliki unsur negatif. Di sela 


\section{8| The Journal of Society and Media 3(1)}

kegiatan, koordinator kegiatan menghimbau peserta agar selalu menjaga kebersihan taman dengan tidak membuang sampah sembarangan. Lahan Taman Flora yang sangat luas dan cocok digunakan untuk perkemahan sekolah karena suasanya yang mirip dengan hutan. Dalam kegiatan perkemahan ini memberikan keuntungan selain anak bisa belajar mengenal alam, mereka juga menerapkan teori-teori yang selama ini hanya diajarkan dikelas kedalam dunia yang sesungguhnya.

Area outbound hanya dikhususkan untuk pengunjung anak-anak. Area ini berfungsi untuk melatih keberanian dan ketangkasan anak. Di area ini anak-anak bisa memanfaatkan alat yang telah disediakan pengelola secara gratis namun harus tetap didampingi oleh orang tua. Selanjutnya spot yang bisa digunakan untuk sarana pembelajaran adalah taman promosi kesehatan yang didalamnya terdapat beragam tanaman yang biasa digunakan sebagai pengubatan tradisional. Lahan Taman Flora yang sangat luas membuat kegiatan perkemahan sering diadakan beberapa sekolah. Taman ini memilikiBroadband Learning Center (BLC) yang merupakan tempat pembelajaran dan pelatihan IT. Namun untuk mengikuti kursus ini harus melakuka pendafataran terlebih dahulu. Fasilitas ini ditunjang dengan peralatan lengkap komputer serta instruktur yang berkompeten.

Taman Bacaan Masyarakat (TBM) merupakan sebuah perpustakaan yang memiliki beragam koleksi yang mampu menambah pengetahuan pengunjung. Tidak semua taman di Surabaya memiliki fasilitas ini. Pemerintah kota berharap dengan adanya TBM akan semakin meningkatkan minat baca masyarakat yang selama ini menurun. Sarana pembelajaran lain yakni adanya rumah kompos yang letaknya berada diluar taman yang merupakan tempat pengolahan sampah untuk dijadikan suatu barang yang memiliki nilai lebih. Selain itu Taman Flora memiliki tempat lain yang dapat menambah wawasan pengunjung yakni Rumah Kompos yang merupakan tempat pengolahan sampah untuk dijadikan suatu barang yang lebih berharga dan memiliki nilai jual. Banyak pelajar yang tertarik untuk mengetahui proses pengolahan sampah. Fungsi dari rumah kompos dijelaskan oleh pengelolanya yakni untuk mengurangi sampah, mengurangi sampah jalanan seperti daun yang gugur atau pohon yang tumbang, mengurangi penggunaan bahan bakar minyak, dijadikan sebagai pembelajaran dan digunakan sebagai sarana penelitian. 


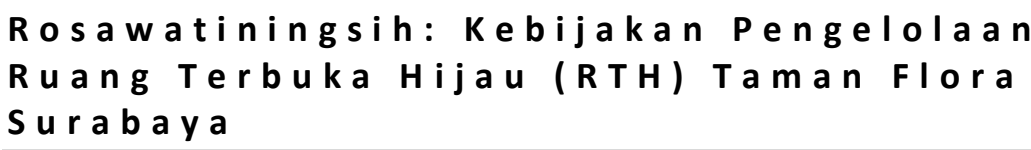

\section{Fungsi Interaksi}

Adanya suatu kegiatan di suatu tempat tentu selalu ada komunikasi yang terjalin. Komunikasi sebagai sarana interaksi di Taman Flora terjadi pada sesama manusia, alam, dan sang pencipta. Hal ini mengandung salah satu unsur kebudayaan yakni bahasa. Pengunjung Taman Flora terdiri dari berbagai suku sehingga penggunaan bahasa yang berbeda seperti bahasa madura, suroboyoan, jawa dapat ditemui disana. Interaksi dengan sesama manusia bisa dilihat antar sesama pengunjung, pengelola, pedagang. Interaksi yang terjalin dilakukan untuk menentukan suatu kesepakatan dan menghindari terjadinya penyimpangan. Seperi orang tua yang menghimbau anaknya untuk menjauhi area taman yang berbahaya, transaksi jual beli pedagang dengan pembeli untuk menyepakati harga, komunikasi antar pengelola untuk mengerjakan bagian taman mana yang harus dirawat terlebih dahulu, komunikasi pelatih dengan peserta kursus Broadband Learning Center. Interaksi dengan alam tampak saat pengunjung mematuhi peraturan dengan tidak menginjak rumput, tidak melakukan kegiatan pengerusakan fasilitas taman, tidak melakukan pencoretan, membuang sampah pada tempatnya. Sementara interaksi manusia dengan tuhan diwujudkan pengelola dengan adanya fasilitas musholla sebagai tempat ibadan umat muslim agar tidak lupa saat melakukan kegiatan berekreasi.

\section{Fungsi Kesehatan}

Ketika pagi hari khususnya di hari minggu dan libur nasional kegiatan olahraga seperti lari-lari kecil, bulu tangkis,sepak bola, dan senam. Secara tidak langsung, seluruh pengunjung Taman Flora telah memperoleh fungsi ini. Saat memasuki pintu masuk utama, hawa sejuk dari pepohonan yang rindang bisa dirasakan diantara polusi udara akibat aspa kendaraan bermotor. Banyaknya pepohonan hijau dapat menghilangkan penat dan menyegarkan mata. Fasilitas yang memadai membuat fungsi kesehatan bisa diperoleh secara maksimal. Taman Flora memiliki area jogging track yang bisa digunakan pengunjung untuk berjalan santai ataupun lari-lari kecil hingga bersepeda. Adanya 3 alat kesehatan baru di dekat pendopo bisa digunakan untuk mengencangkan otot yang sudah mulai meregang. Kesenangan yang diperoleh pengunjung bisa menghilangkan racun- 
racun yang ada dalam tubuh, sehingga pengunjung bisa kembali beraktifitas dengan positif.

\section{Fungsi Perekonomian}

Taman Flora sebagai destinasi wisata memegang peranan yang besar dalam perputaran uang. Meskipun segala fasilitas yang disediakan pengelola bisa dinikmati secara gratis dan tanpa ada pungutan biaya akan tetapi mampu meningkatkan perekonomian orang-orang yang ada di sekitar sana seperti pedagang dan tukang parkir. Pengembangan area untuk pedagang dilakukan dengan membuat sentra kuliner sebagai pusat makanan dan minuman serta oleholeh bagi pengunjung. Sistem sewa diterapkan pemerintah kota kepada pedagang maupun tukang parkir setiap bulannya. Pedagang diharuskan menyetor sejumlah biaya terkait penggunaan air, listrik, kebersihan dan sewa tempat, sementara tukang parkir menggunakan sistem pembayaran per blok. Pengunjung juga merasa diuntungkan dengan adanya pedagang serta tukang parkir karena memudahkan mereka dalam melakukan kegiatan berwisata. Tidak hanya itu, pemerintah juga diuntungkan dengan hal ini karena dengan dibukanya Taman Flora dan semakin banyak pengunjung akan dapat meningkatkan pemasukan daerah yang nantinya akan berguna bagi pengelolaan taman itu sendiri. Dari hal tersebut dapat dilihat bahwa selain menjalankan fungsi ekonomi, keberadaan tukang parkir dan pedagang juga menjadi salah satu wujud hubungan sosial yang membentuk terjadinya interaksi satu dengan yang lainnya.

\section{Struktur Sosial di Taman Flora}

Taman Flora tidak bisa dilihat sebagai suatu taman yang berdiri sendiri, taman ini memiliki struktur sosial yang terdiri dari beberapa aspek yang memiliki status dan peran saling berkaitan sehingga membentuk suatu sistem. Jika dihubungkan dengan unsur-unsur kebudayaan (Geertz 1992), maka kegiatan berekreasi di Taman Flora tentu memiliki hubungan dengan mata pencaharian. Mulai dari pedagang makanan, oleh-oleh, pakan ternak, mainan anak tersedia dengan harga terjangkau. Pedagang yang ada di Taman Flora terdiri dari pedagang resmi yang ada di sentra kuliner, pedagang yang tidak memiliki stand dan biasa 


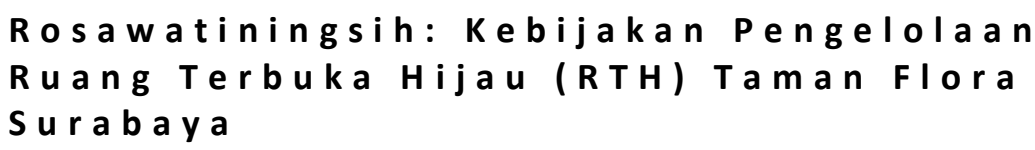

berjualan di sisi pagar pintu masuk dan pedagang yang berkeliling taman. Organisasi sosial menjadi unsur budaya selanjutnya yang ada di Taman Flora. Ada banyak komunitas yang mengurus ijin kepada pengelola untuk dapat menggunakan fasilitas Taman Flora dengan gratis. Namun perijinan yang diurus harus minimal satu bulan sebelum acara dilakukan karena banyak sekali pihak yang ingin menyewa spot taman untuk kegiatan mereka sehingga terkadang harus sabar mengantri.

Secara tidak sadar, setiap orang yang ada di Taman Flora memiliki peran dan fungsi masing-masing yang memperlancar proses kegiatan. Fungsi ekonomi, kesehatan, edukasi, interaksi akan selalu berjalan meski ada salah satu peran yang tidak dilaksanakan. Hal ini disebabkan karena akan selalu ada peran pengganti yang secara otomatis mengisi kekurangan dari peran tadi. Misalnya ada pengelola yang sakit dan ijin maka akan ada pengelola lain yang akan melakukan pekerjaan dari pengelola yang ijin tersebut. Melihat ke struktur yang lebih teknis yakni pemerintah kota sebagai pemegang kebijakan dan memiliki kewenangan yang paling besar. Ketika ada rotasi pegawai atau mutasi maka pegawai baru sudah paham tentang tata kelola taman dan segera melakukan pekerjaannya sesuai dengan tugas pokok dan fungsi yang diemban. Fokus dari teori struktural fungsionalisme ada pada kekekalan struktur sosial yang ada pada masyarakat dalam menjaga hubungan sosial. Hal tersebut selaras ketika diterapkan dengan keberadaan Taman Flora sebagai tempat rekreasi. Struktur sosial dari Taman Flora adalah yang pemerintah,pengunjung, pedagang, pihak swasta, pengelola Taman Flora, hingga tukang parkir.

Belajar dari kesalahan sebelumnya dalam melakukan pengelolaan Taman Flora, kini pemerintah terus berupaya untuk mengembangkan kondisi taman dan berusaha memenuhi kebutuhan pengunjung. Salah satunya dengan cara berkolaborasi dengan pihak swasta, memperkenalkan taman kota yang dimiliki Surabaya sehingga masyarakat luar kota tidak hanya tahu tentang Taman Bungkul saja karena masih banyak taman-taman lain yang perlu dieksplorasi.

Pengelolaan Taman Flora dilakukan pemerintah dengan cara menjalin kerjasama dengan pihak swasta. Pihak swasta menyalurkan program Corporate Social Responsibility (CSR) di Taman Flora dalam berbagai bentuk seperti permainan dan hewan. Pengelola sebagai pihak internal menjalankan fungsi 
rekreasi, edukasi, kesehatan, juga memfasilitasi komunitas dalam fungsi interaksi. Pelaku struktur sosial yang ada di Taman Flora Surabaya dijelaskan secara terperinci dalam uraian berikut:

1. Instruktur Broadband Learning Center (BLC) bertugas untuk memberi pelatihan komputer dan hal yang berkaitan dengan pengembangan teknologi terkini kepada para peserta, melakukan pengawasan dan penjagaan terhadap peralatan yang ada di tempat tersebut sehingga ketika terjadi kerusakan fasilitas bisa segera dilaporkan.

2. Pengelola Taman Bacaan Masyarakat (TBM) memiliki fungsi untuk piket penjagaan,mengelola ruang baca dan memberi peringatan kepada pengunjung yang melakukan penyimpangan serta memberikan informasi serta ajakan agar banyak pengunjung Taman Flora yang mau mampir membaca dan meminjam buku.

3. Pengelola Rumah Kompos berfungsi untuk mengelola sampah, memilah sampah, melakukan proses pencacahan dengan mesin khusus, pembalikan sampah, memantau suhu mesin agar tetap stabil, setelah itu melakukan proses penyaringan dan mendistribusikan hasil dari sampah kompos ke pihak yang telah melakukan perjanjian kerjasama di awal.

4. Petugas Keamanan berfungsi untuk menjaga keamanan, menghalau PKL, mengawasi tindakan perusakan tanaman, dan hal negatif lain yang dilakukan pengunjung di taman.

5. Pengunjung bertugas untuk menjaga kebersihan lingkungan dengan cara membuang sampah pada tempatnya, mematuhi rambu dan larangan yang diberikan petugas, mnejaga segala fasilitas yang telah disediakan dan tidak melakukan pengerusakan.

6. Pedagang di Taman Flora menjalankan fungsi perekonomian dengan cara menjajakan barang dagangannya kepada pengunjung yang membutuhkan. Mayoritas pedagang yang ada memang menjadikan profesi ini sebagai sumber penghasilan utama dalam mencari nafkah untuk keluarganya.

7. Tukang parkir juga menjalankan perputaran ekonomi dengan cara menjaga kendaraan yang dibawa pengunjung dan melakukan penataan kendaraan dengan rapi agar akses masuk ke Taman Flora tidak tertutup.

\section{KESIMPULAN}




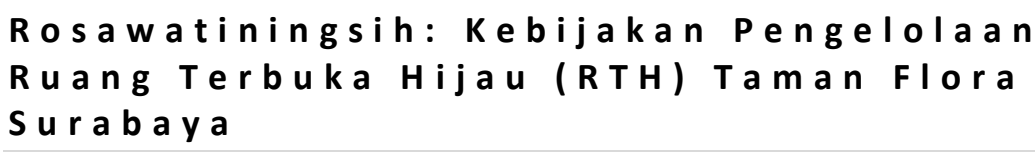

Berawal dari kurangnya minat masyarakat untuk melakukan perjalanan wisata di taman kota atau Ruang Terbuka Hijau (RTH) lain karena pengelolaan yang kurang maksimal membuat pemerintah mulai berbenah diri. Dengan adanya Peraturan MenteriPU No. 05/PRT/M Tahun 2008 tentang Pedoman Penyediaan dan Pemanfaatan Ruang Terbuka Hijau di Kawasan Perkotaan membuat pemerintah kota Surabaya semakin memberi perhatian lebih dalam mengelola taman yang ada di Kota Surabaya, khususnya Taman Flora.Taman Flora kini bukan hanya sekadar taman, melainkan fungsinya jauh lebih kompleks mulai dari fungsi rekreasi, fungsi edukasi, fungsi interaksi, fungsi kesehatan dan fungsi perekonomian. Fungsi-fungsi tersebut bisa dirasakan karena ada struktur sosial yang terus dijaga oleh pihak yang bersangkutan. Pengembangan kondisi serta fungsi taman dilakukan pemerintah kota secara berkala dan berkesinambungan dengan menjalin kerjasama dengan berbagai pihak. Pemerintah, pihak swasta, pengunjung, pedagang hingga tukang parkir memiliki peran sangat penting dan tidak dapat dipisahkan. Pengunjung memiliki kontribusi paling besar dalam hal memberikan kritik dan saran untuk pengelolaan Taman Flora agar lebih baik. Selanjutnya, pedagang dan tukang parkir berperan dalam menjalankan fungsi perekonomian di Taman Flora karena bertugas untuk memenuhi kebutuhan pengunjung, sehingga memperoleh imbalan sebagai balas jasa.

Inti dari berbagai fungsi Taman Flora sebagai Ruang Terbuka Hijau (RTH) adalah melihat taman sebagai suatu sistem yang terdiri dari berbagai struktur sosial dimana struktur tersebut memiliki peran sesuai dengan status yang disandangnya. Seluruh struktur memiliki tugas yang dilandasi oleh nilai dan norma dalam membentuk unsur-unsur kebudayaan diantaranya bahasa, kesenian, mata pencaharian, organisasi sosial hingga sistem peralatan dan teknologi. Setiap struktur memiliki hubungan sosial dalam menjalin kerjasama demi pengembangan Taman Flora sebagai Ruang Terbuka Hijau (RTH) yang lebih baik.

\section{REFERENSI}

Barbosa, O. et. A. (2006). Who benefits from access to green space? A case study from Sheffield, UK. Landscape and Urban Planning 83, 187-195.

Bjerke, T\&Strumse, E. (2006). Vegetation density of urban parks and perceived appropriateness for recreation. Urban Forestry\&Urban Greening, 35-44. 
Carmona. (2003). Public Space Urban Space” The Dimention of Urban Design. London: Architectural Press London.

Creswell, J. W. (2015). Penelitian Kualitatif \& Desain Riset: Memilih di Antara Lima Pendekatan, (Edisi Indonesia, Cetakan I). Yogyakarta: Pustaka Pelajar.

Geertz, C. (1992). Kebudayaan dan Agama. Yogyakarta: Kanisius Press.

Irmadella, A. (2018). Model Kolaborasi Stakeholders dalam Pengelolaan Ruang Terbuka Hijau (RTH) Taman Bungkul Kota Surabaya. Jurnal Kebijakan Dan Manajemen Publik, Vol 6 No.

Iswari, A. N. (2014). Strategi Dinas Kebersihan dan Pertamanan Kota Surabaya (DKP) dalam Pengelolaan Ruang Terbuka Hijau (RTH) untuk Mewujudkan Pembangunan Berkelanjutan dan Berwawasan Lingkungan. Surabaya: Fakultas Ilmu Sosial dan Ilmu Politik Universitas Airlangga.

Kaplan, David \& Manners, A. A. (2002). Teori Budaya. Yogyakarta: Pustaka Pelajar.

Konijnendijk, C. . (2003). A decade of urban forestry in Europe. Forest Policy and Economic, 5, 173-186.

Laurie, M. (1986). Pengantar kepada Arsitektur Pertamanan. Bandung: Intermatra.

Maria Ulfa, L. (2018). Collaborative Governance Dalam Penyediaan Ruang Terbuka Hijau (RTH) Taman Kota di Surabaya. Surabaya: Fakultas Ilmu Sosial dan Ilmu Politik Universitas Airlangga.

Moleong, L. J. (2005). Metode Penelitian Kualitatif Edisi Revisi. Bandung: Remaja Rosda Karya.

Peraturan Menteri Dalam Negeri No. 01 tahun 2007 Tentang Penataan Ruang Terbuka Hijau Kawasan Perkotaan. (n.d.).

Peraturan Menteri PU No. 05/PRT/M Tahun 2008 tentang Pedoman Penyediaan dan Pemanfaatan Ruang Terbuka Hijau di Kawasan Perkotaan. (n.d.).

Pertamanan, D. K. dan. (2014). Profil Dinas Kebersihan dan Pertamanan Kota Surabaya Tahun 2014. Surabaya.

Pesona Taman Kota Surabaya. (2013).

Pitana, I. G. dan G. (2005). Sosiologi Pariwisata. Denpasar: ANDI Yogyakarta.

Pramitasari, D. A. (2009). Taman Flora Sebagai Ruang Terbuka Hijau Bagi Warga Kota Surabaya. Surabaya: Fakultas Ilmu Sosial dan Ilmu Politik Universitas Airlangga Surabaya.

Rakhsandehroo, Mehdi, D. (2015). The Social Benefits of Urban Open Green Spaces: A Literatur Review. Management Research and Practice, Volume 7(Issue 4/2015 PP), 60-71.

Randrup, T.B., Konijnendijk, C.C., Dobbertin, M.K., P. R. (2005). The concept of urban forestry in Europe. Urban Forests and Trees, 9-21.

Saifuddin, A. F. (2005). Antropologi Kontemporer: Suatu Pengantar Kritis Mengenai Paradigma. Jakarta: Prenada Media.

Soekadijo, R. G. (2000). Anatomi Pariwisata Memahami Pariwisata Sebagai 
Rosawatiningsih: Kebijakan Pengelolaan

Ruang Terbuka Hijau (RTH) Taman Flora

Sur a b a y a

Systemic Linkage. Jakarta: PT Gramedia Pustaka Utama.

Sulis Tia Ningsih, Ucha Jaya Sucipta Jaya Sucipta, M. S. P. (2018). IMAJINASI

DESA IMPIAN: Konstruksi Media dalam Pengembangan Desa Wisata di Desa Ranuklindungan Kabupaten Pasuruan. The Journal of Society \& Media, 2(1), 65-80.

Surabaya, A. P. T. F. (2015). Data Daftar Perijinan Pengunjung, Denah, Susunan Pengelola. Arsip tidak dipublikasi.

Taman-Taman Kota di Surabaya. (n.d.).

Undang-Undang No. 10 Tahun 2009 Tentang Kepariwisataan. (n.d.).

Wolch, Jennifer, et. A. (n.d.). Urban Green Space, Public Health, and Environmental Justice. The Challenge of Making Cities 'Just Green Enough.'

Yin, R. K. (2008). Studi Kasus (Desain Dan Metode), (Case Study Research Design and Methods”) diterjemahkan oleh Drs. M. Djauzi Mudzakir, MA. Jakarta: PT.Raja Grafindo Persada.

Zhao, S. (2016). Chinese industrial park planning strategies informed by American edge citie's development path-case study of china (Chongzuo)thailand industrial park. Science Direct. 